\title{
Urinary Lithiasis and Idiopathic Hypercalciuria: The Importance of Dietary Intake Evaluation
}

\author{
Patricia C. G. Damasio, Carmen R. P. Amaro, Silvia J. P. Berto, Natalia B. Cunha, Ana C. \\ Pichutte, Carlos R. Padovani, Joao L. Amaro
}

Lithotripsy Service (PCGD, CRPA), School of Medicine, UNESP, Department of Nursing (SJPB), School of Medicine, UNESP, School of Nutrition (NBC, ACP), UNESP, Department of Biostatistics (CRP), School of Medicine, UNESP, Department of Urology (JLA), School of Medicine, UNESP, Botucatu, Brazil

\begin{abstract}
Purpose: To evaluate food intake of patients with urinary lithiasis and idiopathic hypercalciuria (IH).

Materials and Methods: Between August 2007 and June 2008, 105 patients with lithiasis were distributed into 2 groups: Group $1(\mathrm{n}=55)$ - patients with IH (urinary calcium excretion $>250 \mathrm{mg}$ in women and $300 \mathrm{mg}$ in men with normal serum calcium); Group $2(\mathrm{n}=50)$ - normocalciuria $(\mathrm{NC})$ patients . Inclusion criteria were: age over 18 , normal renal function (creatinine clearance $\geq 60 \mathrm{~mL} / \mathrm{min}$ ), absent proteinuria and negative urinary culture. Pregnant women, patients with some intestinal pathology, chronic diarrhea or using corticoids were excluded. The protocol of metabolic investigation was based on non-consecutive collection of two 24-hour samples for dosages of: calcium, sodium, uric acid, citrate, oxalate, magnesium and urinary volume. Food intake was evaluated through the quantitative method of Dietary Register of three days. Results: Urinary excretion of calcium (433.33 \pm 141.92 vs. $188.93 \pm 53.09)$, sodium (280.08 \pm 100.94 vs. $200.44 .93 \pm$ $65.81)$, uric acid ( $880.63 \pm 281.50$ vs. $646.74 \pm 182.76)$ and magnesium ( $88.78 \pm 37.53$ vs. $64.34 \pm 31.84)$ was significantly higher in the IH group in comparison to the $\mathrm{NC}$ group $(\mathrm{p}<0.05)$. As regards the nutritional composition of food intake of $\mathrm{IH}$ and $\mathrm{NC}$ groups, there was no statistical significant difference in any nutrient evaluated.

Conclusion: In our study, no difference was observed in the food intake of patients with urinary lithiasis and IH or NC.
\end{abstract}

Key words: lithiasis; hypercalciuria; metabolic evaluation; food intake

Int Braz J Urol. 2010; 36: 557-62

\section{INTRODUCTION}

Urinary lithiasis has multifactorial causes, depending on different factors such as hereditariness, climate, anatomic alterations and urinary tract infection, metabolic disorders and food intake (1).

Nearly $95 \%$ of patients with lithiasis present metabolic alterations (2), and, in Brazil, this prevalence may range $93-97 \%$ of cases $(3,4)$. Some of the metabolic causes of stones are hypercalciuria, hypocitraturia, gouty diathesis, hyperoxaluria and hyperuricosuria (5). Idiopathic hypercalciuria (IH) is the most frequently detected metabolic disorder, varying according to the evaluated region $(3,6)$. It is defined by elevated urinary excretion of calcium, in the presence of normocalcemia (7).

Among the environmental factors, food intake is highly important to prevent urinary lithiasis recurrence. This way, the role of some dietary nutrients, mainly calcium, protein and sodium, have been 
recently investigated for their likely effects as either promoters or inhibitors of calculus formation (8).

This study aims to evaluate food intake of patients with urinary lithiasis and IH.

\section{MATERIALS AND METHODS}

Between August 2007 and June 2008, 105 patients with lithiasis were prospectively studied at the Outpatient Clinic of Metabolism in Renal Lithiasis of the Clinical Hospital of Botucatu. This study was approved by the Bioethics Commission of the School of Medicine - UNESP, Botucatu.

Inclusion criteria were: age over 18 years, normal renal function (creatinine clearance $\geq 60 \mathrm{~mL} /$ $\mathrm{min}$ ), absence of proteinuria and negative uroculture at the moment of evaluation. Pregnant women, patients with any intestinal pathology (chronic diarrhea or Crohn's Disease), calcium metabolism disorders (primary hyperparathyroidism, hyperthyroidism, osteoporosis) or patients who used corticoids were excluded.

The metabolic investigation protocol consisted of non-consecutive collection of two samples of 24-hour urine for dosages of calcium, sodium, uric acid, citrate, oxalate, magnesium and urinary volume. Serum dosage of calcium, phosphorus, uric acid, sodium and parathormone was performed in all patients.

The patients were distributed into two groups. $\mathrm{IH}$ was considered the urinary excretion of calcium $>250 \mathrm{mg}$ for women and $300 \mathrm{mg}$ for men with normal serum calcium. Group $1(\mathrm{n}=55)-$ consisted of patients with IH; Group $2(\mathrm{n}=50)$ - Normocalciuric (NC), were considered as patients with normal urinary excretion of calcium.

Food intake was evaluated through the quantitative method of 3-day food record (9). One day on the weekend and two non-consecutive weekdays were fixed (10). The NutWin (2002) - Program of Nutrition Support of Paulista School of Medicine of the Federal University of Sao Paulo was used to calculate the total daily consumption of calories, carbohydrates, lipids, total protein, animal protein and calcium of the patients during the 3-day food record. Sodium $(\mathrm{Na})$ excreted in the 24-hour urine was used as a marker of the daily sodium consumption (11).

Body Mass Index (BMI) was calculated and classified according to World Health Organization (WHO) (12).

Student's-t parametric test was used for independent samples to compare the groups of patients with calcium and non-calcium urinary lithiasis in relation to the quantitative variables studied when the variable presented adherence to Gaussian distribution; and the Wilcoxon-Mann Whitney nonparametric test was used in cases of non-adherence. Considering the study of the association between pairs of variables, Pearson's linear correlation was used (13). Differences were considered significant for $\mathrm{p}$ value $<0.05$.

\section{RESULTS}

Among the 105 patients studied, there was homogeneous distribution in both groups as regards mean age, weight, height and BMI (Body Mass Index) (Table-1). However, it was observed that, in average, according to BMI, patients in both groups were overweighed.

Among the IH patients, there were $60 \%$ of women in a proportion to men of $1.5: 1$, and $56 \%$ in a proportion of 1.27:1 in the NC group. There was no statistically significant difference between the groups $(\mathrm{p}>0.05)$.

In the IH groups, the 24-hour urine volume was between 1,000 and 2,000 mL and in 9\% higher than $2,000 \mathrm{~mL}$. As for the NC group, $78 \%$ was between 1,000 and $2,000 \mathrm{~mL}$, and $4 \%$ higher than 2,000 $\mathrm{mL}$. There was no significant difference between the groups $(\mathrm{p}>0.05)$.

The mean urinary excretion of calcium, sodium, uric acid and magnesium was significantly higher in the IH group than in the NC group (Table2).

As for the nutritional composition of food intake, there was no statistically difference in the average evaluated nutrients in none of the groups (Table-3).

On average, the protein intake was similar in both groups (Table-3). 
Table 1 -Demographics characteristics of the different studied groups.

\begin{tabular}{lccc}
\hline & IH $(\mathrm{N}=55)$ & Group & Statistical Analysis \\
\hline Age (years) & $42.11 \pm 10.61$ & $46.14 \pm 11.52$ & $\mathrm{p}>0.05$ \\
Weight $(\mathrm{kg})$ & $77.14 \pm 16.03$ & $75.99 \pm 15.80$ & $\mathrm{p}>0.05$ \\
Height (meters) & $1.64 \pm 0.10$ & $1.64 \pm 0.08$ & $\mathrm{p}>0.05$ \\
BMI $\left(\mathrm{kg} / \mathrm{m}^{2}\right)$ & $28.78 \pm 5.81$ & $28.07 \pm 5.27$ & $\mathrm{p}>0.05$ \\
Volume $(\mathrm{mL} / 24 \mathrm{~h})$ & $1433.55 \pm 474.81$ & $1314.40 \pm 392.39$ & $\mathrm{p}>0.05$ \\
\hline
\end{tabular}

$B M I=$ body mass index $; I H=$ Idiopathic hypercalciuria $; N C=$ Normocalciuric .

\section{COMMENTS}

Overweight was observed in both groups. These data corroborate other authors $(12,14)$, who demonstrated increased incidence of lithiasis in obese and overweighed patients of both genders.

Epidemiologic studies showed higher prevalence of the lithiasis in male patients (15), however, until now there has been no explanation for this predominance. A transversal analysis in this study showed higher predominance in women in both groups. Other similar studies do not show remarkable differences as for gender (16). These findings can be justified by the higher level of commitment of women in the outpatient follow-up, without reflecting the general gender prevalence in relation to the population with lithiasis.

The risk of calculus formation decreases when the urinary volume is higher than $2,000 \mathrm{~mL}$ and low volume may be considered a risk factor as well as a metabolic disorder for lithiasis (17). This series observed higher predominance of urinary volume between 1,000 and 2,000 $\mathrm{mL}$ in both groups; there was no interference of this parameter. There was no statistically significant difference between the groups.

High intake of sodium decreases the renal absorbency of calcium leading to increased calciuria $(17,18)$, therefore it can be inferred that sodium plays an important role in the genesis of lithiasis.

The excretion of uric acid was significantly higher in the IH group which can be explained by the high prevalence of mixed metabolic alterations in our series and their relation to the elevated animal protein intake observed.

Urinary excretion of magnesium was significantly higher in the IH group. Similar data have been described by other authors (18), who reported

Table 2 - Description of median and standard deviation of biochemical characteristics of 24-hour urine in the different studied groups.

\begin{tabular}{lccc}
\hline Urinary Excretion & IH $(\mathrm{N}=55)$ & Group & Statistical Analysis \\
\hline Calcium $(\mathrm{mg} / 24 \mathrm{~h})$ & $433.33 \pm 141.92$ & $188.93 \pm 53.09$ & \\
Sodium $(\mathrm{mEq} / 24 \mathrm{~h})$ & $280.08 \pm 100.94$ & $200.44 \pm 65.81$ & $\mathrm{p}<0.05$ \\
Uric acid $(\mathrm{mg} / 24 \mathrm{~h})$ & $880.63 \pm 281.50$ & $646.74 \pm 182.76$ & $\mathrm{p}<0.05$ \\
Magnesium $(\mathrm{mg} / 24 \mathrm{~h})$ & $88.78 \pm 37.53$ & $64.34 \pm 31.84$ & $\mathrm{p}<0.05$ \\
Citrate $(\mathrm{mg} / 24 \mathrm{~h})$ & $563.64 \pm 505.45$ & $454.89 \pm 361.98$ & $\mathrm{p}>0.05$ \\
Oxalate $(\mathrm{mg} / 24 \mathrm{~h})$ & $34.57 \pm 23.41$ & $42.40 \pm 28.10$ & $\mathrm{p}>0.05$ \\
\hline
\end{tabular}

$I H=$ Idiopathic hypercalciuria $;$ NC $=$ Normocalciuric. 
Table 3 - Description of median and standard deviation of the composition of daily food intake in the different studied groups.

\begin{tabular}{lccc}
\hline \multicolumn{1}{c}{ Nutrient } & \multicolumn{2}{c}{ Group } & Statistical Analysis \\
& IH $(\mathrm{N}=55)$ & NC $(\mathrm{N}=50)$ & \\
\hline Energy (kcal) & $2046.70 \pm 1405.42$ & $1791.62 \pm 536.03$ & $\mathrm{p}>0.05$ \\
Proteins (g) & $81.78 \pm 37.65$ & $82.06 \pm 29.27$ & $\mathrm{p}>0.05$ \\
Protein (g/kg weight/day) & $1.10 \pm 0.47$ & $1.10 \pm 0.40$ & $\mathrm{p}>0.05$ \\
Animal protein (\%) & $64.33 \pm 42.01$ & $64.78 \pm 29.46$ & $\mathrm{p}>0.05$ \\
Carbohydrates (g) & $243.10 \pm 82.03$ & $227.57 \pm 83.70$ & $\mathrm{p}>0.05$ \\
Lipids (g) & $63.08 \pm 26.53$ & $64.22 \pm 20.71$ & $\mathrm{p}>0.05$ \\
Calcium (mg) & $520.13 \pm 245.62$ & $531.44 \pm 299.48$ & $\mathrm{p}>0.05$ \\
\hline
\end{tabular}

$I H=$ Idiopathic hypercalciuria $; N C=$ Normocalciuric .

a directly proportional relation between urinary calcium and magnesium (19). However, studies about the role of magnesium in urinary lithiasis are highly controversial $(4,20)$.

Although there was no difference in the ingestion of different nutrients in the studied groups, the calcium intake was lower than that recommended to patients with lithiasis, which should range between 800 to $1,000 \mathrm{mg}$ of calcium/day (21). This fact is likely due to the patients' belief that low calcium intake could reduce the recurrence of lithiasis. Therefore, in most cases, calcium restriction is not advisable.

Both groups presented daily protein intake higher than that recommended, as well as high mean intake of animal protein, considering that $50 \%$ of the maximum total intake should be animal protein. However, milk and its by-products, despite their origin, should not be restricted due to the high amount of calcium (21). Some authors (22) have suggested that the incidence of urinary calculi, mainly the calcium originated, is directly related to the amount of animal protein. It is important to recommend lower intake of animal protein to patients with lithiasis, which will contribute to lower lithiasis recurrence. The clinical treatment offered to these patients with lithiasis must include a dietary modification, as well as drug therapies to identify and correct these metabolic disorders thus reducing the recurrence of this pathology.

In our study, no difference was observed in the food intake of patients with urinary lithiasis and $\mathrm{IH}$ or NC.

\section{CONFLICT OF INTEREST}

None declared.

\section{REFERENCES}

1. Heilberg IP, Schor N, Dos Santos DR, Cheidde L, Noronha N, Duarte RJ, et al.: Diretrizes de litíase urinária da sociedade brasileira de nefrologia. J Bras Nefrol. 2002; 24: 2003-7.

2. Levy FL, Adams-Huet B, Pak CY: Ambulatory evaluation of nephrolithiasis: an update of a 1980 protocol. Am J Med. 1995; 98: 50-9.

3. Laranja SMR, Heilberg IP, Coelho STSN, Novoa CG, Schor N: Estudo Multicêntrico de Litíase Renal no Brasil (MULTILIT). In: Schor N, Heilberg IP (ed.), Calculose renal: fisiopatologia, diagnóstico, tratamento. São Paulo, Sarvier. 1995; pp. 295-8.

4. Amaro CR, Amaro JL, Goldberg J: Comportamento do magnésio urinário em pacientes com litíase renal. J Bras Nefrol. 2005; 27: 146-9.

5. Pak CY: Medical management of urinary stone disease. Nephron Clin Pract. 2004; 98: c49-53.

6. Chula DC, Campos RP, Nascimento DE, Carvalho M: Caracterização clínica dos pacientes com hipercalciúria na nefrolitíase. J Bras Nefrol. 2006; 2: 72-6.

7. Hodgkinson A, Pyrah LN: The urinary excretion of calcium and inorganic phosphate in 344 patients with calcium stone of renal origin. Br J Surg. 1958; 46: 10-8.

8. Hess B: Nutritional aspects of stone disease. Endocrinol Metab Clin North Am. 2002; 31: 1017-30. 
9. Burke B: The dietary history as a tool in research. J Am Diet Assoc. 1947; 23: 1041-6.

10. Willett WC: Nutritional epidemiology. In: Rothman KJ, Greenland S (ed.), Modern epidemiology. Philadelphia; Lippincott-Raven Publishers. 1998; pp. 62342.

11. World Health Organization: Reducing Salt intake in populations. Report of a WHO Forum and Technical Meeting" Geneva, World Health Organization [cited 2007 apr 16], 2007. Available at: http://www.who. int/dietphysicalactivity/Salt_Report_VC april07.pdf

12. World Health Organization: Obesity: preventing and managing the global epidemic. Report of a WHO Consultation. WHO Technical Report Series 894. Geneva: World Health Organization [cited 2008 nov 10], 2000. Available at: http:/www.who.int/bmi/index. jsp? introPage $=$ intro_3.html

13. Zar JH: Biostatistical analysis. New Jersey, PrenticeHall. 1999; 4th ed, pp. 663.

14. Taylor EN, Stampfer MJ, Curhan GC: Obesity, weight gain, and the risk of kidney stones. JAMA. 2005; 293: 455-62.

15. Alapont Pérez FM, Gálvez Calderón J, Varea Herrero J, Colome Borros G, Olaso Oltra A, Sánchez Bisono JR: Epidemiology of urinary lithiasis. Actas Urol Esp. 2001; 25: 341-9.
16. Martín JAL, García JRR, Castro SN, Gómez IR, Rosado EF, Castelo LA, et al.: Factores de riesgo metabólico em urolitiasis cálcica según el sexo y edad de los pacientes. Actas Urol Esp. 2006; 26: 111-20.

17. Siener R, Schade N, Nicolay C, von Unruh GE, Hesse $\mathrm{A}$ : The efficacy of dietary intervention on urinary risk factors for stone formation in recurrent calcium oxalate stone patients. J Urol. 2005; 173: 1601-5.

18. Moe OW, Preisig PA: Hypothesizing on the evolutionary origins of salt-induced hypercalciuria. Curr Opin Nephrol Hypertens. 2005; 14: 368-72.

19. Bonny O, Rubin A, Huang CL, Frawley WH, Pak CY, Moe OW: Mechanism of urinary calcium regulation by urinary magnesium and pH. J Am Soc Nephrol. 2008; 19: 1530-7.

20. Dirks JH: The kidney and magnesium regulation. Kidney Int. 1983; 23: 771-7.

21. Baxmann AC, Marques NC, Menon VB, Heilberg IP: Nutrição do paciente com nefrolitíase. In: Barros E, Gonçalves LF (ed.), Nefrologia no consultório. São Paulo, Artmed. 2007; pp. 475-83.

22. Borghi L, Schianchi T, Meschi T, Guerra A, Allegri F, Maggiore U, et al.: Comparison of two diets for the prevention of recurrent stones in idiopathic hypercalciuria. N Engl J Med. 2002; 346: 77-84.

Accepted after revision:

February 18, 2010

\section{Correspondence address:}

Dr. João Luiz Amaro

Faculdade de Medicina de Botucatu

Departamento de Urologia

Botucatu, Sao Paulo, 18618-970, Brazil

E-mail: jamaro@fmb.unesp.br 


\section{Dietary Intake in Idiopathic Hypercalciuria}

\section{EDITORIAL COMMENT}

The cause of urinary calculi is multifactorial as hereditary and environmental factors. The authors have showed no difference in food intake as calcium and animal protein of patients with idiopathic hypercalciuria $(\mathrm{IH})$ and normocalciuria. Hypercalciuria is the evaluation for the calcium stone former, but in this study, authors did not study the composition of the stone. Several studies have reported that the common abnormal metabolic disorders are hypocitraturia and low urine volume, but in this study, urine citrate level is not low and different in both groups. Diet consumption is not the factor of $\mathrm{IH}$ in this study, patients need to be evaluated for the other factors such as absorptive, resorptive or renal hypercalciuria.

\section{REFERENCE}

1. Pak CY. Medical management of urinary stone disease. Nephron Clin Pract. 2004; 98: c49-53.

Dr. Bannakij Lojanapiwat Division of Urology Chiang Mai University Chiang Mai, Thailand E-mail: blojanap@med.cmu.ac.th 